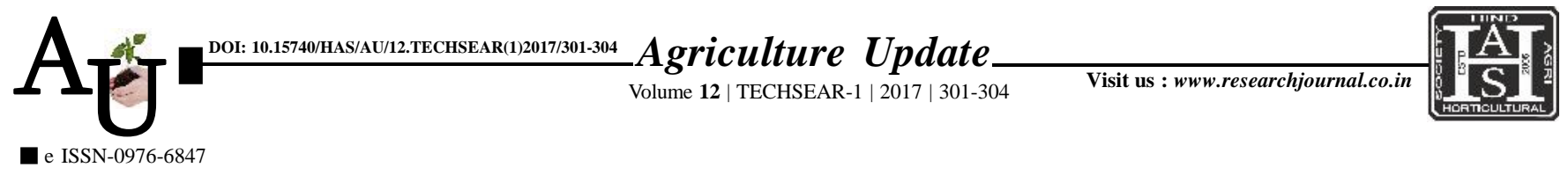

\title{
Rеsearch Note: Effect of boron application through soil and foliar methods on the yield attributes and nutrient uptake of wet land rice
}

\section{RESHMA REMESH AND B. RANI}

Article Chronicle: Received :

11.07.2017;

Accepted :

26.07.2017

KEY WoRds:

Boron, Soil

application, Foliar application, Rice, Yield

Author for correspondence :

\section{RESHMA REMESH}

Food Corporation of India, COIMBATORE (T.N.) INDIA

See end of the article for authors' affiliations
SUMMARY : A field experiment was conducted to evaluate the effect of boron (B) application through soil and foliar methods on the yield attributes and nutrient uptake of wet land rice, at Cropping Systems Research Centre, Karamana, during Rabi season (September to January), 2016. Both soil application $\left(\mathrm{T}_{1}-0.25 \mathrm{~kg} \mathrm{ha}^{-1}, \mathrm{~T}_{2}-0.5 \mathrm{~kg} \mathrm{ha}^{-1}, \mathrm{~T}_{3}-0.75 \mathrm{~kg} \mathrm{ha}^{-1}\right.$ and $\left.\mathrm{T}_{4}-1.0 \mathrm{~kg} \mathrm{ha}^{-1}\right)$ and foliar application $\left(\mathrm{T}_{5}-250 \mathrm{mg}\right.$ lit ${ }^{1}, \mathrm{~T}_{6}-500 \mathrm{mg} \mathrm{L}^{-1}, \mathrm{~T}_{7}-750 \mathrm{mg} \mathrm{L}^{-1}$ and $\mathrm{T}_{8}-1000 \mathrm{mg} \mathrm{L}^{-1}$ ) of $\mathrm{B}$ were given at active tillering and flowering stages in equal splits along with a no B control. Boron application through both methods substantially improved the yield and yield attributes of rice as well as the nutrient uptake as compared to control treatment receiving only NPK fertilizers. However, soil application was better in improving the thousand grain weight, grain yield and harvest index as compared to foliar treatments and control. Foliar application improved the weight per panicle, straw yield and uptake of N, P, K and B. Soil application of B at levels $0.75 \mathrm{~kg} \mathrm{ha}^{-1}$ or above was better than all the foliar levels in producing higher grain yields with significant increase at $1.0 \mathrm{~kg} \mathrm{ha}^{-1} \mathrm{~B}$. No significant difference was obtained in straw yields between any of the foliar treatments and the soil treatments from 0.5 to $1.0 \mathrm{~kg} \mathrm{ha}^{-1} \mathrm{~B}$. Application of B @ $1.0 \mathrm{~kg} \mathrm{ha}^{-1}$ to the soil gave the highest B:C ratio (1.52) which was on par with $0.75 \mathrm{~kg} \mathrm{ha}^{-1} \mathrm{~B}(1.48)$ and with foliar application of 250 $\mathrm{mg} \mathrm{L}^{-1} \mathrm{~B}$ (1.45). A further increase in $\mathrm{B}: \mathrm{C}$ ratio was not noticed at higher foliar application levels which had an inhibitory effect on yield, yield attributes and nutrient uptake of rice. Hence, B may be applied as soil application @ $0.75 \mathrm{~kg} \mathrm{ha}^{-1}$ in two equal splits to get better yields and higher benefit cost ratio.

How to cite this article : Remesh, Reshma and Rani, B. (2017). Effect of boron application through soil and foliar methods on the yield attributes and nutrient uptake of wet land rice. Agric. Update, 12(TECHSEAR-1) : 301-304; DOI: 10.15740/HAS/AU/12.TECHSEAR(1)2017/301-304. 